This is a revised personal version of the text of the final journal article, which is made available for scholarly purposes only, in accordance with the journal's author permissions. The full citation is:

Hakami O., Zhang Y., Banks C.J. (2012) Thiol-functionalised mesoporous silicacoated magnetite nanoparticles for high efficiency removal and recovery of $\mathrm{Hg}$ from water. Water Research 46(12), 3913-3922. doi: 10.1016/j.watres.2012.04.032

\title{
Thiol-functionalised mesoporous silica-coated magnetite nanoparticles for high efficiency removal and recovery of $\mathrm{Hg}$ from water
}

\author{
Othman Hakami * ${ }^{1}$, Yue Zhang, Charles J. Banks \\ Faculty of Engineering and the Environment, University of Southampton, Highfield, \\ Southampton, SO17 1BJ, UK
}

\begin{abstract}
The preparation and testing of thiol-functionalised silica-coated magnetite nanoparticles (TF-SCMNPs) is described. The characteristics of these particles are assessed at different stages in the production process using X-ray diffraction (XRD), transmission electron microscopy (TEM), Fourier Transform Infrared Spectroscopy (FTIR), and a magnetometer. The particles were found to be almost spherical with a uniform mesoporous structure with a pore size of $\sim 2.1 \mathrm{~nm}$. The particles were strongly responsive to an external magnetic field making separation from solution possible in less than 1 min. The adsorption characteristics of the particles were quantified in a series of isotherm experiments using $\mathrm{Hg}$ (II) solution concentrations between 40 and $1000 \mu \mathrm{g}^{-1}$ at adsorbent concentrations of 4 and $8 \mathrm{mg} \mathrm{l}^{-1}$. The adsorption capacity was higher than for other commonly used adsorbents with $90 \%$ of $\mathrm{Hg}(\mathrm{II})$ removed during the first $5 \mathrm{~min}$ and equilibrium in less than $15 \mathrm{~min}$. Both the Langmuir and Freundlich isotherm models were applied to the isotherm data and the maximum adsorption capacity was achieved when the ratio of adsorbent to adsorbate was low. Both
\end{abstract}

\footnotetext{
1 * Corresponding author: Tel.: +44 (0)2380 595464; fax: +44 (0)2380 677519; E-mail address: o.hakami@soton.ac.uk (O. Hakami).
} 
temperature and $\mathrm{pH}$ had an effect on adsorption but when the TF-SCMNPs were used for removal of $\mathrm{Hg}(\mathrm{II})$ from tap water and bottled water, which contained other ions, there appeared to be no interference. $\mathrm{Hg}$ (II) could be successfully desorbed using thiourea in a $3 \mathrm{M} \mathrm{HCl}$ solution; this did not result in the destruction of the nanoparticles and they could subsequently be reused without loss of their activity in repetitive adsorption tests.

Keywords: Mercury, Magnetite, Mesoporous, Adsorption, Desorption

\section{Introduction}

Adsorption is a widely used technique for the removal of low concentrations of heavy metals from water, and the effectiveness of various adsorbents has been demonstrated over many years in different water and wastewater applications (Babel and Kurniawan, 2003; Brown et al., 2001). Activated carbon (AC) is one of the most common industrial adsorbents used for mercury removal (Bailey et al., 1999; Kurniawan et al., 2006; Namasivayam and Kadirvelu, 1999), yet various studies have shown practical limitations. Even in a welloperated system regeneration of the carbon may result in a loss of $\sim 15 \%$ of the original material; this coupled with the use of complexing agents to improve performance can result in substantial waste generation (Babel and Kurniawan, 2003; Bailey et al., 1999). Fly ash (Rio and Delebarre, 2003), clay (U Senevirathna et al., 2011), zeolite (Chojnacki et al., 2004) and peat moss (Brown et al., 2001) have also been commonly used as adsorbents because their structure provides sufficient surface area for adsorption. In all cases, however, the presence of an ill-defined pore structure (Hahn et al., 1996; Yoshitake et al., 2002) has a hindering effect on diffusion, which may lead to a decrease in the adsorption rate and the available capacity (Hu et al., 2006). Ideally, the pores of an adsorbent should facilitate the transport of molecules and provide free access. This can be achieved through interlinked pores with a near uniform size distribution (Yoshitake et al., 2002). 
Magnetic composite particles can be designed to have specific physical, chemical and surface properties that allow the selective attachment of ions, molecules, macromolecules, cells, colloidal particles or liquid phases (Warner et al., 2009; Xu and Dong, 2008). Once the target has attached, the use of a magnet provides a very simple and effective method of separating the particles along with their targeted specific group from the aqueous phase. The manufacture of these magnetic composite particles first requires creation of the nanoparticles and then modification of the surface to match the requirements and constraints of the proposed end use (Hu et al., 2006; Williams, 1994). Of interest in the current research are micro and mesoporous nanomaterials, as these have a high surface area and high porosity (Kanel et al., 2005); this coupled with high reactivity makes them useful as adsorbents in water and wastewater treatment. Functionalised nanoporous adsorbents are therefore now being studied with respect to their possible use in the removal of heavy metals from aqueous media (Da'na and Sayari, 2011; Mamadou et al., 2008; Shahbazi et al., 2010). Among the types examined, those with thiol-functionalised groups have been found to be most efficient for the removal of $\mathrm{Hg}(\mathrm{II})$ (Walcarius and Delacôte, 2005).

The $\mathrm{pH}$ value affects adsorption as it determines the degree of protolysis or 'ionisation' of both the adsorbate and the adsorbent. Since hydrogen and hydroxide ions often interact with adsorbents commonly used in aqueous phase applications, the adsorption of $\mathrm{Hg}$ (II) ions may be strongly influenced by the solution pH (Walcarius and Delacôte, 2005). The temperature of the adsorption medium has also been shown to be important where the mechanism of the metal-binding processes is energy dependent (Green-Ruiz, 2009). Changing the temperature may affect the equilibrium adsorption capacity of the adsorbent: for example, the adsorption 
capacity will decrease with increasing temperature for an exothermic reaction, while it will increase for an endothermic one (Rodda et al., 1996).

In an effective treatment system desorption and regeneration of the adsorbate is an essential requirement, and one of the key factors in this is the ability to maintain adequate performance of the adsorbent in multi-cycle use (Dabrowski, 2001). Hydrochloric acid is commonly used for elution of metal ions, including $\mathrm{Hg}$ (II), from adsorbents due to their high solubility, its common usage in industry and its relatively low cost (Naja and Volesky, 2010). Recovery of the adsorbate may be a secondary objective, and the more concentrated the adsorbate is in the desorption fluid the more likely the success of the process (Brown et al., 2000; Feng et al., 1997). For the removal of $\mathrm{Hg}$ (II) from functional thiol groups, as considered in the current work, acid alone is not effective and the addition of thiourea is required (Huang and Hu, 2008; Pu et al., 2004; Walcarius and Delacôte, 2005).

The current research used thiol-functionalised silica-coated magnetite nano-particles (TFSCMNPs) prepared by co-condensation and characterised using a variety of phyicochemical techniques. The composite particles were then used in an adsorption process for $\mathrm{Hg}$ (II) removal, and the Langmuir and Freundlich isotherm models used to process the adsorption isotherm data. Desorption and regeneration were also examined as the next steps in progressing the application of this new type of adsorbent to more complex aqueous mixes containing other ions and dissolved species typical of what might be found in natural and waste waters.

\section{Materials and methods}

\subsection{Synthesis of TF-SCMNPs}


The procedure used for the preparation of the TF-SCMNPs is shown in Fig. 1S (in supplementary file), and includes three stages: synthesis of the magnetite $\left(\mathrm{Fe}_{3} \mathrm{O}_{4}\right)$ nanoparticles (NPs), applying a mesoporous silica coating, and applying a functional group to the coating. The $\mathrm{Fe}_{3} \mathrm{O}_{4}$ NPs were first prepared using the co-precipitation method described by Kang et al. (1996), with some modifications. In this method, $11.68 \mathrm{~g}$ of $\mathrm{FeCl}_{3} \cdot 6 \mathrm{H}_{2} \mathrm{O}$ and $4.31 \mathrm{~g}$ of $\mathrm{FeCl}_{2} \cdot 6 \mathrm{H}_{2} \mathrm{O}$ were dissolved over a 30 -min period in $200 \mathrm{ml}$ of deionised water, which was maintained at $85^{\circ} \mathrm{C}$ whilst being vigorously stirred and bubbled with nitrogen gas. After the ferric and ferrous chloride were dissolved, and while still continuing to bubble nitrogen, $\sim 20 \mathrm{ml}$ of $30 \%$ (w/v) aqueous $\mathrm{NH}_{3}$ solution was added dropwise into the iron mixture until the colour of the bulk solution changed from orange to black and the $\mathrm{pH}$ increased to 8.0. An external magnetic field was then applied and the black magnetite precipitate was immobilised while the supernatant was removed by decantation.

The second-stage application of the mesoporous silica coat to form SCMNPs itself followed a four-step procedure as shown in Fig. 1S (in supplementary file; Liu et al., 1998; Wu and $\mathrm{Xu}, 2005$ ). First, dense liquid-silica-coated magnetite nanoparticles (DLSC-Fe $\mathrm{O}_{4}$ ) were prepared by re-suspending the $\mathrm{Fe}_{3} \mathrm{O}_{4} \mathrm{NPs}$ in $150 \mathrm{ml}$ of deionised water in a $500 \mathrm{ml}$ threenecked round-bottomed flask with the contents agitated by immersion in an ultrasonic bath (Crest Ultrasonic CP1100, UK). The $\mathrm{pH}$ of the suspension was then raised to $9.5 \pm 0.1$ by adding $0.1 \mathrm{M} \mathrm{NaOH}$, and it was stirred and heated at $90^{\circ} \mathrm{C}$ for $2 \mathrm{~h}$ under a nitrogen atmosphere. A volume of $10 \mathrm{ml}$ of aqueous silica solution $\left(\mathrm{Na}_{2} \mathrm{SiO}_{3}\right)$ was then added, followed by $0.1 \mathrm{M} \mathrm{HNO}_{3}$ to maintain the $\mathrm{pH}$ at 9.5 . Second, for molecular templating, $75 \mathrm{ml}$ of DLSC-Fe $\mathrm{O}_{4}$ suspension was added to $100 \mathrm{ml}$ of ethanol and stirred for $30 \mathrm{~min}$, followed by addition of a $75 \mathrm{mmol}^{-1}$ Cetyltrimethylammonium chloride aqueous solution. The mixture was allowed to react at room temperature for $3 \mathrm{~h}$ while mixing continued. Third, for 
the sol-gel process, the silica precursor, tetraethoxysilane was added and stirred for a further $5 \mathrm{~h}$ at room temperature before $60 \mathrm{ml}$ of glycerol were added. The $\mathrm{pH}$ was adjusted to 4.6 using glacial acetic acid and a drop of ammonia solution added to act as a catalyst. The mixture was then stirred for a further $3 \mathrm{~h}$ under a nitrogen atmosphere to ensure complete dehydration. The SCMNPs at this stage are mesoporous, but the pores are filled with the surfactant. To remove the surfactant, as the fourth step in the treatment, the SCMNPs were calcinated at $540^{\circ} \mathrm{C}$ in a tube furnace with nitrogen flow for $4 \mathrm{~h}$.

Before the third stage of adding a functional group to the coating, $3 \mathrm{~g}$ of mesoporous SCMNPs were hydrolysed in $100 \mathrm{~mL}$ of toluene. The suspension was stirred for $2 \mathrm{~h}$ under a nitrogen atmosphere. The functional group was then added by washing $25 \mathrm{ml}$ of SCMNPs with ethanol $(2 \times 100 \mathrm{ml})$. The particles were dispersed in the solvent by immersing the flask in an ultrasonic bath, then separated from the solvent using a permanent magnet and diluted to $150 \mathrm{ml}$ with 1\% 3-mercaptopropyl trimethoxysilane (3-MPTMS) in 95\% ethanol, followed by the addition of $16 \mathrm{mmol}^{-1}$ of acetic acid to adjust the $\mathrm{pH}$ to 4.5. The suspension was then transferred to a $500 \mathrm{ml}$ three-necked round-bottomed flask, stirred and heated at $60{ }^{\circ} \mathrm{C}$ for $2 \mathrm{~h}$ under a nitrogen atmosphere. The particles were then washed three times with deionised water, twice with methanol and residual solvent was removed using a freeze dryer (VirTis Bench Top 6K, UK).

All chemicals used in the preparation were obtained from either Fisher Scientific Ltd (UK), or Sigma-Aldrich Co (UK).

\subsection{Characterisation of TF-SCMNPs}


The purity of the TF-SCMNPs was verified using a number of techniques. X-ray diffraction (XRD) patterns were obtained using a Philips XPert Pro vertical goniometer instrument. $\mathrm{Cu}$ K $\alpha$ radiation $(\lambda=1.5406 \AA$ ) was used with an accelerating voltage and applied current of 40 $\mathrm{kV}$ and $40 \mathrm{~mA}$. The XRD patterns obtained were step-scanned from $2^{\circ}$ to $80^{\circ}(2 \theta)$ at $0.02^{\circ}$ or $0.01^{\circ}$ increments using a counting time of $10 \mathrm{~s}$ per increment. Transmission electron microscopy (TEM) images of the TF-SCMNPs were obtained using a JEM 3010 microscope (Japan Electron Co.). The particles were first dispersed in ethanol for $45 \mathrm{~min}$ using sonication and then transferred to a copper grid (Carbon Films, 200 Mesh Grids, AGAR). The TEM images were obtained using bright-field image mode at $200 \mathrm{kV}$ acceleration voltage. Spectra of the TF-SCMNPs particles were obtained using samples dried at room temperature for $24 \mathrm{~h}$, and then $100 \mathrm{mg}$ was mixed with potassium bromide and pressed to form pellets. These were analysed by Fourier Transform Infrared Spectroscopy (FTIR) using a Nicolet Protégé 460 FTIR spectrometer (Thermo, UK) in transmission mode at room temperature and scanning 32 times in the spectral ranges 400 and $4000 \mathrm{~cm}^{-1}$ with a spectral resolution of $4 \mathrm{~cm}^{-1}$. The magnetic behaviour of the TF-SCMNPs was characterised using a vibrating sample magnetometer (VSM, 3001) with hysteresis measurements being performed at $300 \mathrm{~K}$ with applied magnetic fields of up to $0.9 \mathrm{~T}$ in order to achieve demagnetisation corrections. The zeta potential $(\xi)$ and dynamic light scattering of TFSCMNPs was determined by ME11 Zetasizer Nano ZS (Malvern Instruments Ltd, UK) at $25{ }^{\circ} \mathrm{C}$. A folded capillary cell (DTS1060) filled with $1 \mathrm{ml}$ of the TF-SCMNPs suspension was used for the measurement.

\subsection{Adsorption experiments}

Adsorption experiments were carried out by mixing TF-SCMNPs with $50 \mathrm{ml}$ of a $\mathrm{Hg}(\mathrm{II})$ solution made up at different concentrations in $0.1 \mathrm{M} \mathrm{NaNO}$ to keep the ionic strength 
relatively constant. All sorption experiments were carried out in duplicate in $100 \mathrm{ml}$ polyethylene terephthalate (PET) bottles placed in an orbital incubator at $200 \mathrm{rpm}$ for $1 \mathrm{~h}$ at $22.5^{\circ} \mathrm{C}$ unless otherwise noted. The $\mathrm{pH}$ of the suspension was adjusted by adding either $0.1 \mathrm{M} \mathrm{NaOH}$ or $0.1 \mathrm{M} \mathrm{HNO}_{3}$. Adsorption tests were carried out at $\mathrm{pH}$ values in the range 2.09.0 using $\mathrm{Hg}(\mathrm{II})$ concentrations 40, 80, 200, 500 and $1000 \mu \mathrm{g} \mathrm{l}^{-1}$ in a $50 \mathrm{ml}$ solution to which was added a known quantity of either 0.20 or $0.40 \mathrm{mg}$ of a concentrated TF-SCMNP suspension to give nanoparticle concentrations of 4 and $8 \mathrm{mg} \mathrm{l}^{-1}$. The TF-SCMNPs were reacted for $1 \mathrm{~h}$ to reach equilibrium and then separated by applying an external magnetic field. The final concentration of $\mathrm{Hg}$ (II) was determined using a PSA 10.035 Millennium Merlin atomic fluorescence spectrometry (P S Analytical Ltd, UK) with a detection limit of $2.0 \mathrm{ng} \mathrm{1}^{-1}$. Dissolved iron was measured using an inductively coupled plasma-atomic emission spectrometer (Varian Vista Pro ICP-OES, UK; detection limit $=0.19 \mathrm{mg} \mathrm{l}^{-1}$ ).

The adsorption capacity $\left(q_{e}, \mathrm{mg} \mathrm{g}^{-1}\right)$, the amount of $\mathrm{Hg}(\mathrm{II})$ adsorbed at equilibrium, was calculated according to the following equation:

$$
q_{e}=\frac{V\left(C_{0}-C_{e}\right)}{m}
$$

where $C_{o}$ is the initial mercury concentration in solution $\left(\mathrm{mg}^{-1}\right), C_{e}$ is the equilibrium concentration (mg $\mathrm{m}^{-1}$ ) after adsorption, $V$ is the solution volume (l), $m$ is the mass of NPs adsorbent $(\mathrm{g})$.

The Langmuir equation (Langmuir, 1916) given in Eq. (2) was applied to the data to provide an insight into the mechanism of the adsorption.

$$
\frac{C_{e}}{q_{e}}=\frac{1}{Q_{0} b}+\frac{C_{e}}{Q_{0}}
$$


where $Q_{0}$ and $b$ are Langmuir constants related to the maximum adsorption capacity and energy of adsorption respectively. Likewise, the Freundlich equation (Freundlich, 1926) given in Eq. (3) was also applied in the form

$$
\log q_{e}=\log K_{f}+n^{-1} \log C_{e}
$$

where $K_{f}$ and $n^{-1}$ are Freundlich constants incorporating all factors that affect the adsorption process such as capacity and intensity, respectively.

\subsection{Desorption and regeneration experiments}

Desorption of $\mathrm{Hg}$-laden TF-SCMNPs was tested using $\mathrm{HCl}$ at concentrations from 1.0 to 5.0 M containing 2\% (m/v) thiourea. Before this acid treatment the magnetically recovered TFSCMNPs were first washed three times with deionised water to remove any $\mathrm{Hg}(\mathrm{II})$ which was loosely attached to the PET bottles or to the adsorbent itself. A $5 \mathrm{ml}$ aliquot of the desorbent was then added to each PET bottle and the bottles were shaken for $1 \mathrm{~h}$ to ensure the contact between TF-SCMNPs and adsorbent. The TF-SCMNPs were separated magnetically from the desorbent and its mercury concentration was determined. The desorption efficiency was then calculated as

$$
\text { Desorptioncapacity }=\frac{\left(C_{e d}-C_{o}\right) V_{d}}{q_{e} M} \times 100
$$

where $C_{e d}$ is the equilibrium concentration $\left(\mathrm{mg}^{-1}\right)$ after desorption, $C_{0}$ is the initial concentration of mercury in the eluent $\left(\mathrm{mg} \mathrm{l}^{-1}\right), V_{d}$ is the volume of the eluent (1), $q_{e}$ is the adsorption capacity obtained in the adsorption test and $M$ is the mass of TF-SCMNPs adsorbent.

To determine the regeneration capacity, three concentrations of $\mathrm{Hg}(\mathrm{II})$ solutions were used, each over five adsorption-desorption cycles. In each test an $8 \mathrm{mg}^{-1}$ suspension of TF- 
SCMNPs was used with $50 \mathrm{ml}$ of 80,120 and $200 \mu \mathrm{g}^{-1}$ of $\mathrm{Hg}$ (II) solutions, according to the procedure described above.

\section{Results and discussion}

\subsection{Characterisation of adsorbent (TF-SCMNPs)}

Fig. 1a shows the XRD diffraction patterns in which six diffraction peaks $(220,311,400$, 442, 511 and 440) are seen and indexed to the spinal structure of pure magnetite nanoparticles (trace i), with no other crystalline phases detected. The XRD pattern of TFSCMNPs (trace ii) shows that the mesoporous spheres have similar diffraction peaks suggesting that the magnetic core was unchanged within the silica matrix.

A typical TEM image for the $\mathrm{Fe}_{3} \mathrm{O}_{4} \mathrm{NPs}$ is shown in Fig. 1b, and shows them to be nearly spherical with a diameter of around $50 \mathrm{~nm}$. The bright-field image at high magnification of the TF-SCMNPs (Fig. 1c) shows a lamellar mesostructure with a well-defined hexagonal arrangement of uniform pores. The pore size was estimated to be $\sim 2.1 \mathrm{~nm}$ and the detail was obtained by focusing a direct electron beam parallel to the main axis of the pores.

Fig. 2a shows the FTIR spectrograph of $\mathrm{Fe}_{3} \mathrm{O}_{4}$ NPs, SCMNPs and TF-SCMNPs. $\mathrm{For} \mathrm{Fe}_{3} \mathrm{O}_{4}$ $\mathrm{NPs}$, the peaks at 516.20 and $593.38 \mathrm{~cm}^{-1}$ are attributed to the $\mathrm{Fe}-\mathrm{O}$ bond vibration of $\mathrm{Fe}_{3} \mathrm{O}_{4}$, while the peak at 1630.88 also shows the existence of Fe-O. The absorption bonds at 582.57 $\mathrm{cm}^{-1}$ revealed the presence of Fe-O-Si. The FTIR spectrum of the SCMNPs shows strong absorption characteristics at $\mathrm{Si}-\mathrm{O}$ bands of 789.15 and $1082.49 \mathrm{~cm}^{-1}$. There is also a weak band at $962.80 \mathrm{~cm}^{-1}$ corresponding to the $\mathrm{Si}-\mathrm{OH}$ bending vibration. The broad absorption band at $3421.33 \mathrm{~cm}^{-1}$ was due to $\mathrm{O}-\mathrm{H}$ stretching vibration, which corresponds to hydroxyl groups on the surface of iron oxide and this band can be assigned to the adsorbed water 
molecules. Additional bands were observed at 2855.42 and 2964.29 and these correspond to $\mathrm{CH}_{3}$ and $\mathrm{CH}_{2}$ vibrations, respectively. $\mathrm{S}-\mathrm{H}$ stretches were found at $2509.93 \mathrm{~cm}^{-1}$, which are typically very weak and convoluted by contamination of the $\mathrm{CO}_{2}$ stretching bands from the background. Generally, the S-H stretching band is characteristically weak and cannot be detected in the spectra of dilute solutions or thin films (Silverstein et al., 2005). The FTIR spectra show, however, that the surface of TF-SCMNPs contains an (-SH) group which results from the modification procedure with 3-MPTMS.

Fig. $2 \mathrm{~b}$ shows that the saturation magnetisation of $\mathrm{Fe}_{3} \mathrm{O}_{4} \mathrm{NPs}$ at room temperature is $\sim 0.60$ emu while the saturation magnetisation of SCMNPs was $0.25 \mathrm{emu}$ : this reduction as a result of the silica coat was expected. The functionalisation of the SCMNPs with 3-MPTMS only caused a decrease of a further $12 \%$ giving a final emu of 0.20 , making it still very strongly responsive to an external magnetic field. As shown in Fig. 2Sa (in supplementary file) permanent magnet placed adjacent to the suspension was able visibly to clarify it within the space of one min; the total Fe in solution was below the sample detection limit of ICP-OES which is $<0.19 \mathrm{mg}^{-1}(<2.3 \%$ of the initial concentration). The magnetically separated TFSCMNPs are not permanently magnetised and can be re-dispersed without any signs of reaggregation when the external magnetic field is removed. The average hydrodynamic size of TF-SCMNPs was measured before and after separation and was found to be 111.06 and $111.30 \mathrm{~nm}$, respectively.

\subsection{Adsorption Kinetics}

Fig. 3a shows that the rate of $\mathrm{Hg}$ (II) uptake was initially high, with about $90 \%$ of $\mathrm{Hg}(\mathrm{II})$ removed during the first $5 \mathrm{~min}$. There was then a gradual reduction in rate of removal leading to an equilibrium condition which was achieved within less than 15 min with $100 \%$ 
$\mathrm{Hg}$ (II) adsorbed. The rapid adsorption might be attributed to two factors: first, there is a chemical binding between $\mathrm{Hg}$ (II) ions and the surface functional groups; second, there is electrostatic attraction between the external surface of the adsorbent and the metal ion. For comparison Table 1S (in supplementary file) shows the equilibrium time for the removal of $\mathrm{Hg}(\mathrm{II})$ ions using some common adsorbents.

\subsection{Adsorption Isotherm}

To derive data for the adsorption isotherm, initial concentrations of 40, 80, 120, 160, 200, 400, 600, 800 and $1000 \mu \mathrm{g} \operatorname{Hg}(\mathrm{II}) \mathrm{1}^{-1}$ were used with the TF-SCMNPs adsorbent at 4 and 8 mg $1^{-1}$. Fig. 3b shows that, as expected, the amount of $\mathrm{Hg}(\mathrm{II})$ ions adsorbed per unit mass of the TF-SCMNPs increased with the decreased weight of the adsorbent. From this plot of adsorbed $\mathrm{Hg}(\mathrm{II})\left(\mathrm{q}_{\mathrm{e}}\right)$ against the equilibrium concentration $\left(\mathrm{C}_{\mathrm{e}}\right)$ at $\mathrm{pH} 6.0$, the loading capacity of the TF-SCMNPs was found to be 113.7 and $207.7 \mathrm{mg} \mathrm{g}^{-1}$ when applied to concentrations of 8 and $4 \mathrm{mg} \mathrm{l}^{-1}$ of adsorbent, respectively. In both cases the initial mercury concentration of the solution was $1000 \mu \mathrm{g} \mathrm{1^{-1 }}$. Table $2 \mathrm{~S}$ (in supplementary file) gives a comparison with other adsorbents used for the adsorption of $\mathrm{Hg}$ (II) as reported in the literature: it is clear that TF-SCMNPs have a higher adsorption capacity for $\mathrm{Hg}$ (II) with much lower effluent mercury concentration.

The adsorption data were fitted to both the Langmuir and Freundlich isotherm models, which can describe the equilibrium between $\operatorname{Hg}(\mathrm{II})$ adsorbed $\left(\mathrm{q}_{\mathrm{e}}\right)$ and in solution $\left(\mathrm{C}_{\mathrm{e}}\right)$ when at constant temperature. The difference in the models is that Langmuir assumes that adsorption takes place at specific homogenous sites within the adsorbent and is suited to monolayer adsorption processes, whereas Freundlich assumes the uptake of the adsorbates occurs on a heterogeneous surface by multi-layer adsorption. 
The plots for Ce/qe against $C e$ for both quantities of adsorbent are shown in Fig. $4 \mathrm{a}, \mathrm{b}$ with a linear regression line fitted. The values of the Langmuir constants $Q_{0}$ and $b$ were calculated from the slope and intercept of this line and are shown in Table 1. The correlation coefficient $\mathrm{R}^{2}>0.97$ for the data to the model indicates monolayer adsorption of the $\mathrm{Hg}(\mathrm{II})$ to the surface of TF-SCMNPs at the concentrations of adsorbent and adsorbate applied. The different quantities of adsorbent gave different sorption capacities of 113.7 and $207.7 \mathrm{mg}$ $\mathrm{Hg} \mathrm{g}^{-1}$. A higher maximum capacity was achieved when the ratio of adsorbent to adsorbate was lower, as the maximum capacity calculated from the Langmuir equation is not a constant but a function of this ratio.

The experimental data were also plotted in accordance with the Freundlich model (Fig. 4c, d) and the constants obtained are shown in Table 1. The correlation coefficients $\left(\mathrm{R}^{2}\right)$ between the experimental data and the model were 0.99 and 0.97 for the two different quantities of adsorbent used suggesting that heterogeneous conditions exist. It might therefore be the case that the TF-SCMNPs provide heterogeneity by virtue of having different functional groups and a complex porous structure. The Freundlich parameter $1 / n$ gave values of 0.47 and 0.48 for the two different adsorbent quantities of TF-SCMNPs indicating that $\mathrm{Hg}(\mathrm{II})$ can be effectively removed from aqueous solutions.

\subsection{Effect of $\mathrm{pH}$}

At concentrations higher than $50 \mathrm{mg} \mathrm{l}^{-1}, \mathrm{Hg}(\mathrm{II})$ is likely to precipitate from solution. To mitigate this effect the test used $50 \mathrm{ml}$ aliquots of $\mathrm{Hg}(\mathrm{II})$ at concentrations of $80,200,500$ and $1000 \mu \mathrm{g} \mathrm{l}^{-1}$ mixed with TF-SCMNPs at a concentration of $8 \mathrm{mg} \mathrm{l}^{-1}$ for $1 \mathrm{~h}$ to reach equilibrium. The test was carried out at $\mathrm{pH}$ values ranging from 2.0 to 9.0. 
The results showed that there was a decrease in removal efficiency at all $\mathrm{pH}$ values with increasing concentration of the $\mathrm{Hg}$ (II) solution (Fig. 5a). At the two lower concentrations of $\mathrm{Hg}$ (II) solution there was no effect on removal efficiency between $\mathrm{pH} 2.0$ and 7.0. There was a reduction in removal efficiency at the higher $\mathrm{Hg}(\mathrm{II})$ concentrations at the lower $\mathrm{pH}$ values, and above $\mathrm{pH} 7$ there was a small decrease in efficiency of removal. These results support the findings of Walcarius and Delacôte (2005) who also showed an independence of the effects of $\mathrm{pH}$ on adsorption when using -SH functional groups. The high selectivity and affinity for $\mathrm{Hg}$ by the thiol-functionalised group is a possible explanation for this (Mattigod et al., 2007). This affinity is predicted on the basis of the hard and soft acid base theory, which directly correlates the degree of cation softness with the observed strength of interaction with base functionalities, such as $-\mathrm{SH}$ groups. The relatively large ionic size, low electronegativity, and high polarisability (highly deformable bonding electron orbital) of $\mathrm{Hg}$ are characteristics of a soft acid, and as the thiol group is a soft base they have a high affinity to each other.

The surface charges of TF-SCMNPs and of TF-SCMNPs that had been contacted with $\mathrm{Hg}(\mathrm{II})$ solutions $1000 \mu \mathrm{g} \mathrm{1^{-1 }}$ was studied by measuring the zeta potential at $\mathrm{pH}$ values ranging from 2 to 8 , this was seen to decreased with increasing $\mathrm{pH}$, as shown in Fig. $5 \mathrm{~b}$. The TF-SCMNPs contacted with a $1000 \mu \mathrm{g} \mathrm{l}^{-1} \mathrm{Hg}(\mathrm{II})$ solution had a positive charge at $\mathrm{pH} 2$ and 3 in comparison to negative zeta potential of the nanoparticles in a mercury-free solution at the same $\mathrm{pH}$.

The mechanism of adsorption at different $\mathrm{Hg}$ (II) concentrations might be interpreted as follows. The zeta potential of nanoparticles solution in a mercury-free environment is 
negative at the entire range of $\mathrm{pH}$ tested. The adsorption is expected to occur by chemical binding, therefore, between the negative-charged nanoparticles and positive-charged $\mathrm{Hg}(\mathrm{II})$. In the case of a lower initial concentration of $\mathrm{Hg}(\mathrm{II}) \leq 200 \mu \mathrm{g}{ }^{-1}$, all of the $\mathrm{Hg}$ was adsorbed at the lower $\mathrm{pH}$ as there were sufficient protonated ligand sites available. At $\mathrm{pH}$ values above $\mathrm{pH}$ of point of zero charge $\left(\mathrm{pH}_{\mathrm{pzc}}\right)$, adsorption of $\mathrm{Hg}$ was complete as expected. While the initial $\mathrm{Hg}(\mathrm{II})$ concentrations reach above a certain level, the apparent zeta potential of nanoparticles-mercury complex becomes positive. This indicates that other adsorption mechanisms, such as ion exchange, might also play a role in the $\mathrm{pH}$ range below $\mathrm{pH}_{\mathrm{pzc}}$ allowing more $\mathrm{Hg}$ to attach to the adsorbent.

\subsection{Bottled or tap water matrix and coexisting ions}

The initial experiments to assess the adsorption properties of the nanoparticles were carried out with $\mathrm{Hg}(\mathrm{II})$ dissolved in deionised water. Practical applications would, however, be for the removal of very low concentrations of $\mathrm{Hg}(\mathrm{II})$ from water sources or treated wastewater. As a first step in assessing the effect that an interaction between $\mathrm{Hg}$ (II) and dissolved ions could have on adsorption, some tests were carried out using bottled and tap water as the solute. The ion concentration $\left(\mathrm{mg} \mathrm{l}^{-1}\right)$ of the bottled water used is shown in Table $3 \mathrm{~S}$ (in supplementary file). Initial $\mathrm{Hg}$ concentrations of 80, 120, 160, 200, 400, 600, 800, $1000 \mu \mathrm{g} \mathrm{1^{- }}$

${ }^{1}$ were used with the TF-SCMNPs adsorbent at $8 \mathrm{mg} \mathrm{l}^{-1}$ and the results given in Fig. 6a indicate that there was no interference with the maximum adsorption capacity for $\mathrm{Hg}(\mathrm{II})$. The value of $111.93 \mathrm{mg} \mathrm{Hg} \mathrm{g}^{-1}$ for bottled water was about the same as when deionised water was used as the solute. The maximum adsorption capacity calculated using the Langmuir model slightly decreased to $98.45 \mathrm{mg} \mathrm{Hg} \mathrm{g}^{-1}$ when using tap water as adsorption matrix. 


\subsection{Effect of temperature}

The removal efficiency of $\mathrm{Hg}$ (II) from $100 \mathrm{ml}$ of $160 \mu \mathrm{g}{ }^{-1} \mathrm{Hg}$ solution by TF-SCMNPs at a concentration of $6 \mathrm{mg}^{-1}$ was tested at $10,22.5$ and $35{ }^{\circ} \mathrm{C}$. The results in Fig. $6 \mathrm{~b}$ show removals of $93.48 \%$ at $10^{\circ} \mathrm{C}, 93.76 \%$ at $22.5{ }^{\circ} \mathrm{C}$ and $82.99 \%$ at $35{ }^{\circ} \mathrm{C}$. The uptake at 10 and $22.5{ }^{\circ} \mathrm{C}$ was almost the same, but decreased between $22.5{ }^{\circ} \mathrm{C}$ to $35{ }^{\circ} \mathrm{C}$. This result corresponds with those of Tsai et al. (2005) who suggested that in an exothermic adsorption process, the quantity of adsorbate taken up increases with a decrease in adsorption temperature. The variation in the adsorption may be as a result of an increased tendency of $\mathrm{Hg}(\mathrm{II})$ to escape as the temperature of the reaction mixture rises (Jeon and Ha Park, 2005). As the temperature rises, the fraction of $\mathrm{Hg}$ that can escape from the surface increases and the amount adsorbed decreases, resulting in a reduction in boundary layer thickness (Jeon and Ha Park, 2005). A similar observation has been reported by Zhou et al. (2009) who used thiourea-modified magnetic chitosan microspheres for the adsorption of $\mathrm{Hg}$ (II).

\subsection{Desorption study}

When using strong acid it is possible that desorption could occur as a result of acid solubilisation of the nanoparticle. This was checked by using $5 \mathrm{M} \mathrm{HCl}$ in a desorption trial. The result showed that $15.9 \%$ of Fe incorporated in the nanoparticles was dissolved, indicating that this strength of acid is not suitable as a regenerent. Table 2 shows that the desorption efficiency decreases with decreasing $\mathrm{HCl}$ concentration and that $5 \mathrm{ml}$ of a $1.0 \mathrm{M}$ $\mathrm{HCl}$ solution only gave $10 \%$ recovery of $\mathrm{Hg}(\mathrm{II})$. Results for subsequent tests which used a mixture of $\mathrm{HCl}$ and thiourea for desorption, are given in Table 2, and show that reducing the concentration of $\mathrm{HCl}$ from 5.0 to $1.0 \mathrm{M}$ and adding $2 \%$ thiourea gave a desorption efficiency of $\sim 40 \%$. The addition of $5 \mathrm{ml}$ of $3 \mathrm{M} \mathrm{HCl}$ containing $2 \%(\mathrm{~m} / \mathrm{v})$ thiourea as a complexing agent was able to recover $92.28,88.48$ and $87.29 \%$ of $\mathrm{Hg}(\mathrm{II})$ at initial 
concentration of 80,120 and $200 \mu \mathrm{g}^{-1}$, respectively, from the solution. A small amount of iron was dissolved when using $3 \mathrm{M} \mathrm{HCl}$ containing $2 \%(\mathrm{~m} / \mathrm{v})$ thiourea as eluent; however, this was less than $0.19 \mathrm{mg} \mathrm{l}^{-1}$.

\subsection{Regeneration study}

A cycle using the same TF-SCMNPs at a concentration of $8 \mathrm{mg}^{-1}$ was repeated five times, in each case using $50 \mathrm{ml}$ of $80,120,200 \mu \mathrm{g} 1^{-1} \mathrm{Hg}(\mathrm{II})$ solutions in the adsorption cycle and 3.0 $\mathrm{M} \mathrm{HCl}$ and $2 \%(\mathrm{~m} / \mathrm{v})$ thiourea in the desorption cycle. The results are given in Fig. 7 and show that at the end of the fifth cycle the TF-SCMNPs maintained adsorption efficiencies of 94.70, 92.68 and $92.94 \%$ for $\mathrm{Hg}(\mathrm{II})$ solution concentrations of 80,120 and $200 \mu \mathrm{g} 1^{-1}$, respectively. This indicates that there is some reduction in adsorption efficiency and this may be due to $\mathrm{Hg}(\mathrm{II})$ not being released from adsorption sites between cycles.

\section{Conclusions}

- TF-SCMNPs were prepared using a co-condensation pathway and the characterisation of these suggested that the process gave a uniform structure and properties to all of the particles.

- The adsorption data for Hg (II) onto TF-SCMNPs were fitted to the Freundlich and Langmuir isotherm and the maximum capacity for $\mathrm{Hg}$ (II) was calculated to be 207.7 $\mathrm{mg} \mathrm{g}^{-1}$ when $4 \mathrm{mg} \mathrm{l}^{-1}$ of TF-SCMNPs were used.

- Adsorption of $\mathrm{Hg}(\mathrm{II})$ at 10 and $22.5^{\circ} \mathrm{C}$ was almost the same, but decreased when temperature increased to $35^{\circ} \mathrm{C}$.

- The effect of $\mathrm{pH}$ was highly dependent on the initial concentration of $\mathrm{Hg}(\mathrm{II})$.

- Adsorption was not affected by coexisting anions and light cations under the conditions tested. 
- $\mathrm{Hg}(\mathrm{II})$ ions adsorbed on TF-SCMNPs could be desorbed effectively using $3 \mathrm{M} \mathrm{HCl}$ containing $2 \%(\mathrm{~m} / \mathrm{v})$ thiourea showing that the TF-SCMNPs could be regenerated and maintained at almost the same $\mathrm{Hg}$ (II) adsorption capacity.

- The results suggest that TF-SCMNPs could be an effective alternate to conventional adsorbents for the adsorption of $\mathrm{Hg}(\mathrm{II})$ from water at a very high removal efficiency and in a very short time.

\section{Acknowledgment}

The authors would like to thank the Ministry of Higher Education of the Kingdom of Saudi Arabia (University of Jazan) for $\mathrm{PhD}$ funding in support of this work.

\section{References}

Babel, S. and Kurniawan, T.A. 2003.Low-cost adsorbents for heavy metals uptake from contaminated water: a review. Journal of Hazardous Materials 97(1-3), 219-243.

Bailey, S.E., Olin, T.J., Bricka, R.M. and Adrian, D.D. 1999.A review of potentially lowcost sorbents for heavy metals. Water Research 33(11), 2469-2479.

Brown, J., Richer, R. and Mercier, L. 2000.One-step synthesis of high capacity mesoporous $\mathrm{Hg} 2+$ adsorbents by non-ionic surfactant assembly. Microporous and mesoporous materials 37(1-2), 41-48.

Brown, P., Gill, S. and Allen, S. 2001.Metal removal from wastewater using peat. Water Research 34(16), 3907-3916. 
Chojnacki, A., Chojnacka, K., Hoffmann, J. and Górecki, H. 2004.The application of natural zeolites for mercury removal: from laboratory tests to industrial scale. Minerals Engineering 17(7-8), 933-937.

Da'na, E. and Sayari, A. 2011.Effect of regeneration conditions on the cyclic performance of amine-modified SBA-15 for removal of copper from aqueous solutions: Composite surface design methodology. Desalination.

Dabrowski, A. 2001.Adsorption from theory to practice. Advances in Colloid and Interface Science 93(1-3), 135-224.

Feng, X., Fryxell, G.E., Wang, L.Q., Kim, A.Y., Liu, J. and Kemner, K.M. 1997.Functionalized monolayers on ordered mesoporous supports. Science 276(5314), 923-926.

Freundlich, H. 1926.Colloid \& capillary chemistry, Methuen \& co. ltd.

Green-Ruiz, C. 2009.Effect of salinity and temperature on the adsorption of $\mathrm{Hg}$ (II) from aqueous solutions by a Ca-montmorillonite. Environmental technology 30(1), 63-68.

Hahn, K., Kärger, J. and Kukla, V. 1996.Single-file diffusion observation. Physical review letters 76(15), 2762-2765.

Hu, J., Chen, G. and Lo, I.M.C. 2006.Selective removal of heavy metals from industrial wastewater using maghemite nanoparticle: performance and mechanisms. Journal of Environmental Engineering 132, 709.

Huang, C. and Hu, B. 2008.Silica-coated magnetic nanoparticles modified with [gamma]mercaptopropyltrimethoxysilane for fast and selective solid phase extraction of trace amounts of $\mathrm{Cd}, \mathrm{Cu}, \mathrm{Hg}$, and $\mathrm{Pb}$ in environmental and biological samples prior to their determination by inductively coupled plasma mass spectrometry. Spectrochimica Acta Part B: Atomic Spectroscopy 63(3), 437-444. 
Jeon, C. and Ha Park, K. 2005.Adsorption and desorption characteristics of mercury (II) ions using aminated chitosan bead. Water Research 39(16), 3938-3944.

Kanel, S., Manning, B., Charlet, L. and Choi, H. 2005.Removal of Arsenic (III) from Groundwater by Nanoscale Zero-Valent Iron. Environmental Science \& Technology 39(5), 1291-1298

Kang, Y., Risbud, S., Rabolt, J. and Stroeve, P. 1996.Synthesis and Characterization of Nanometer-Size Fe3O4 and [gamma]-Fe2O3 Particles. Chem. Mater 8(9), 2209-2211.

Kurniawan, T.A., Chan, G., Lo, W. and Babel, S. 2006.Comparisons of low-cost adsorbents for treating wastewaters laden with heavy metals. Science of the total environment 366(2-3), 409-426.

Langmuir, I. 1916.The constitution and fundamental properties of solids and liquids. Part I. Solids. Journal of the American Chemical Society 38(11), 2221-2295.

Liu, Q., Xu, Z., Finch, J. and Egerton, R. 1998.A novel two-step silica-coating process for engineering magnetic nanocomposites. Chemistry of materials 10(12), 3936-3940.

Mamadou, D., Duncan, J., Savage, N., Street, A. and Sustich, R. 2008.Nanotechnology Applications for Clean Water. Micro \& Nano Technologies, 700.

Mattigod, S., Fryxell, G. and Parker, K. 2007.A thiol-functionalized nanoporous silica sorbent for removal of mercury from actual industrial waste. Environmental applications of nanomaterials: synthesis, sorbents and sensors, 275 .

Naja, G.M. and Volesky, B. 2010.Treatment of Metal-Bearing Effluents: Removal and Recovery. Handbook on Heavy Metals in the Environment, Taylor \& Francis and CRC Press, Boca Raton, FL, 247-291. 
Namasivayam, C. and Kadirvelu, K. 1999.Uptake of mercury (II) from wastewater by activated carbon from an unwanted agricultural solid by-product: coirpith. Carbon 37(1), 79-84.

Pu, X., Jiang, Z., Hu, B. and Wang, H. 2004. $\gamma$-MPTMS modified nanometer-sized alumina micro-column separation and preconcentration of trace amounts of $\mathrm{Hg}, \mathrm{Cu}, \mathrm{Au}$ and $\mathrm{Pd}$ in biological, environmental and geological samples and their determination by inductively coupled plasma mass spectrometry. Journal of Analytical Atomic Spectrometry 19(8), 984-989.

Rio, S. and Delebarre, A. 2003.Removal of mercury in aqueous solution by fluidized bed plant fly ash. Fuel 82(2), 153-159.

Rodda, D.P., Johnson, B.B. and Wells, J.D. 1996.Modeling the Effect of Temperature on Adsorption of Lead(II) and Zinc(II) onto Goethite at Constant pH. Journal of colloid and interface science 184(2), 365-377.

Shahbazi, A., Younesi, H. and Badiei, A. 2010.Functionalized SBA-15 mesoporous silica by melamine-based dendrimer amines for adsorptive characteristics of $\mathrm{Pb}$ (II); $\mathrm{Cu}$ (II) and Cd (II) heavy metal ions in batch and fixed bed column. Chemical Engineering Journal.

Silverstein, R.M., Bassler, G.C. and Morrill, T.C. 2005.Spectroscopic Identification of Organic Compounds, John Wiley and Sons, New Yourk.

Tsai, W., Hsien, K., Chang, Y. and Lo, C. 2005.Removal of herbicide paraquat from an aqueous solution by adsorption onto spent and treated diatomaceous earth. Bioresource technology 96(6), 657-663. 
U Senevirathna, W., Zhang, H. and Gu, B. 2011.Effect of carboxylic and thiol ligands (oxalate, cysteine) on the kinetics of desorption of $\mathrm{Hg}$ (II) from kaolinite. Water, Air, \& Soil Pollution, 1-12.

Walcarius, A. and Delacôte, C. 2005.Mercury (II) binding to thiol-functionalized mesoporous silicas: critical effect of $\mathrm{pH}$ and sorbent properties on capacity and selectivity. Analytica Chimica Acta 547(1), 3-13.

Warner, M.G., Warner, C.L., Addleman, R.S. and Yantasee, W. 2009.Magnetic Nanomaterials for Environmental Applications.

Williams, R. 1994.Colloid and surface engineering: Applications in the process industries, Butterworth-Heinemann UK.

$\mathrm{Wu}, \mathrm{P}$. and $\mathrm{Xu}, \mathrm{Z}$. 2005.Silanation of nanostructured mesoporous magnetic particles for heavy metal recovery. Industrial \& engineering chemistry research 44(4), 816-824.

Xu, Z. and Dong, J. 2008.Synthesis, characterization, and application of magnetic nanocomposites for the removal of heavy metals from industrial effluents. Emerging Environmental Technologies, 105-148.

Yoshitake, H., Yokoi, T. and Tatsumi, T. 2002.Adsorption of chromate and arsenate by amino-functionalized MCM-41 and SBA-1. Chemistry of materials 14(11), 46034610.

Zhou, L., Wang, Y., Liu, Z. and Huang, Q. 2009.Characteristics of equilibrium, kinetics studies for adsorption of $\mathrm{Hg}(\mathrm{II}), \mathrm{Cu}(\mathrm{II})$, and $\mathrm{Ni}(\mathrm{II})$ ions by thiourea-modified magnetic chitosan microspheres. Journal of Hazardous Materials 161(2-3), 995-1002. 
Table 1- Estimated values for constants for the Langmuir and Freundlich models at different concentrations of TF-SCMNPs and $\mathrm{pH}$ 6.0.

\begin{tabular}{|c|c|c|c|}
\hline \multirow{2}{*}{$\begin{array}{c}\text { Adsorbent } \\
\text { concentration }\left(\mathrm{mg} \mathrm{l}^{-1}\right)\end{array}$} & \multicolumn{2}{|c|}{ Langmuir Constant } & \multirow{2}{*}{$\mathbf{R}^{2}$} \\
\hline & $Q_{0}\left(\mathrm{mg} \mathrm{g}^{-1}\right)$ & $\mathrm{b}\left(1 \mathrm{mg}^{-1}\right)$ & \\
\hline 8 & 113.75 & 0.07 & 0.97 \\
\hline 4 & 207.71 & 0.02 & 0.98 \\
\hline Adsorbent & \multicolumn{2}{|c|}{ Freundlich Constant } & \multirow{2}{*}{$\mathbf{R}^{2}$} \\
\hline concentration $\left(\mathrm{mg} \mathrm{l}^{-1}\right)$ & $K_{f}$ & $1 / n$ & \\
\hline 8 & 14.03 & 0.47 & 0.99 \\
\hline 4 & 8.96 & 0.48 & 0.97 \\
\hline
\end{tabular}


Table 2- Recovery of $\mathrm{Hg}(\mathrm{II})$ species bound to TF-SCMNPs, after desorption using different eluents.

\begin{tabular}{|c|c|c|c|c|c|c|c|}
\hline Hg & & & xtent & desorp & on in differ & it media (\% & \\
\hline Conconcentration & $1 \mathrm{M}$ & $2 \mathrm{M}$ & $3 \mathrm{M}$ & $5 \mathrm{M}$ & 1 M HCl+ & $2 \mathrm{M} \mathrm{HCl}+$ & 3M HCl+ \\
\hline$\left(\mu \mathrm{gl}^{-1}\right)$ & $\mathrm{HCl}$ & $\mathrm{HCl}$ & $\mathrm{HCl}$ & $\mathrm{HCl}$ & $2 \%$ thiourea & 2\% thiourea & $2 \%$ thiourea \\
\hline 80 & 8.78 & 34.32 & 72.18 & 95.18 & 46.39 & 85.69 & 92.28 \\
\hline 120 & 11.48 & 33.99 & 71.24 & 94.27 & 46.48 & 84.60 & 88.48 \\
\hline 200 & 10.17 & 32.62 & 69.90 & 94.82 & 42.87 & 84.30 & 87.29 \\
\hline
\end{tabular}



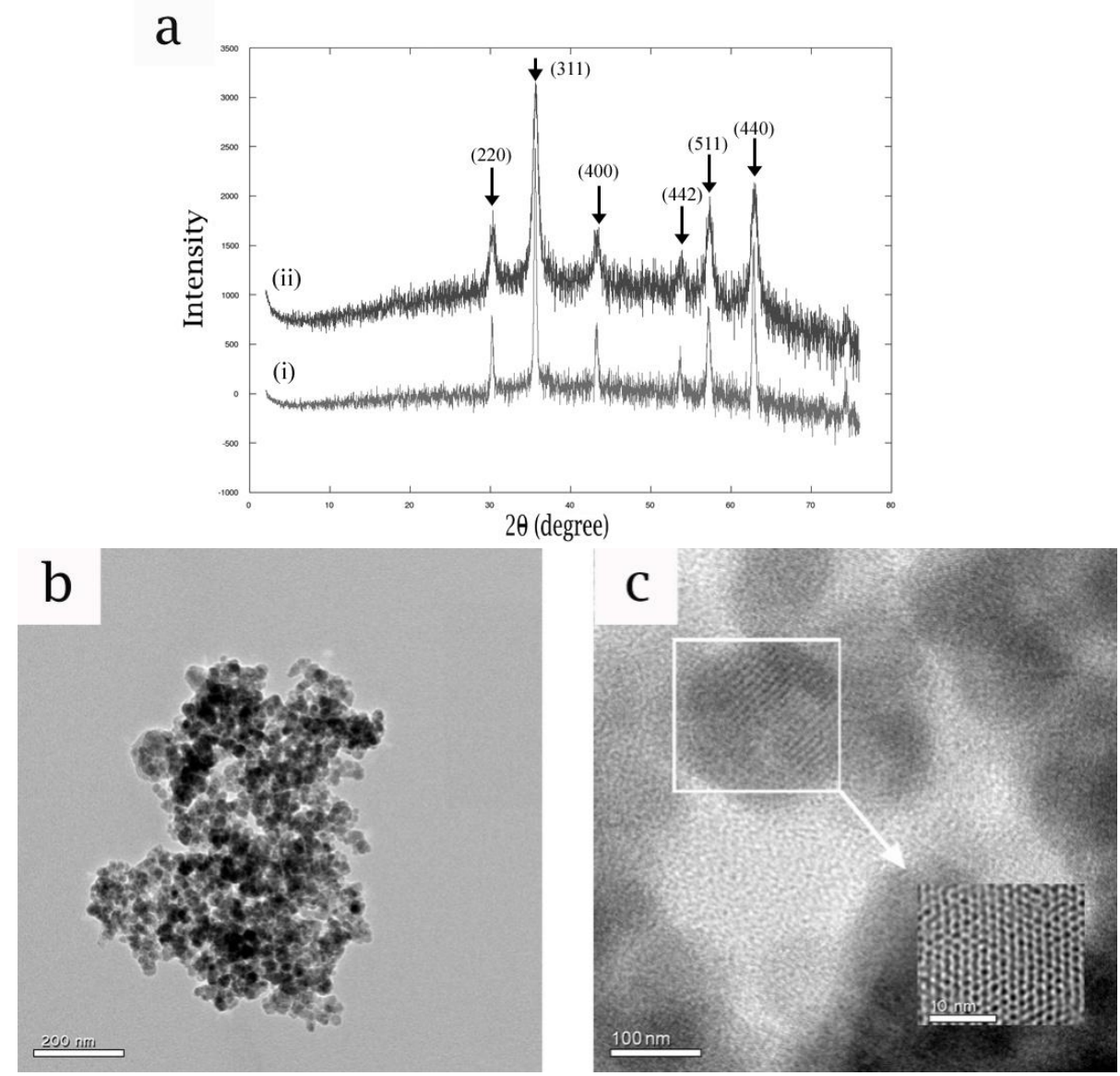

Fig. 1- Structural properties of magnetite and thiol-functionalised silica-coated magnetite nanoparticles (TF-SCMNPs) as shown by X-ray diffraction (XRD) and transmission electron microscopy (TEM). (a) XRD pattern of (i) $\mathrm{Fe}_{3} \mathrm{O}_{4}$ NPs and (ii) TF-SCMNPs. (b) TEM micrograph of $\mathrm{Fe}_{3} \mathrm{O}_{4}$ NPs. (c) TEM of TF-SCMNPs. 
a

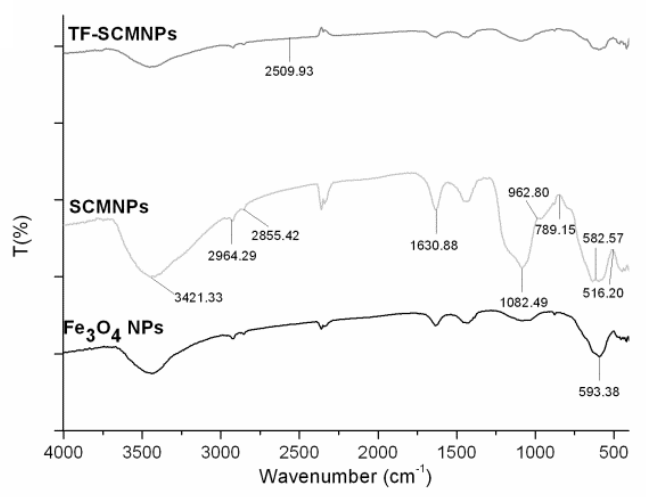

b

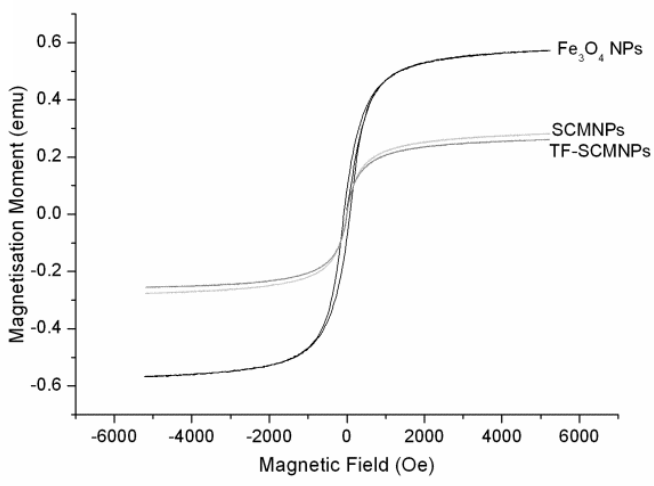

Fig. 2- Surface and magnetic properties of the nanoparticles at different stages of preparation. (a) FTIR spectra of $\mathrm{Fe}_{3} \mathrm{O}_{4}$ NPs, SCMNPs and TF-SCMNPs. (b) Room temperature magnetisation measurement of $\mathrm{Fe}_{3} \mathrm{O}_{4} \mathrm{NPs}$, SCMNPs, TF-SCMNPs. 
a

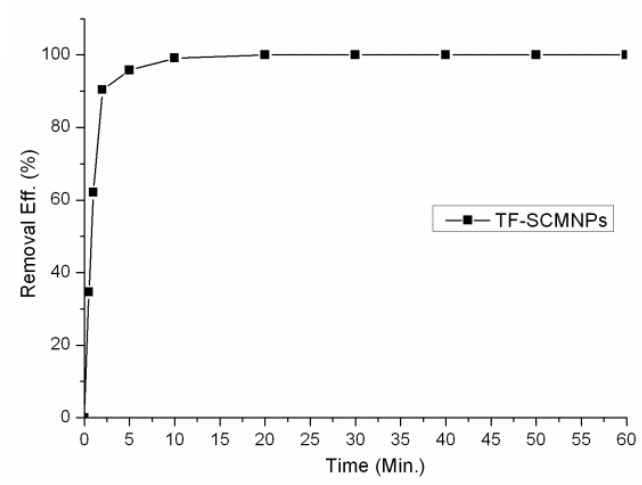

b

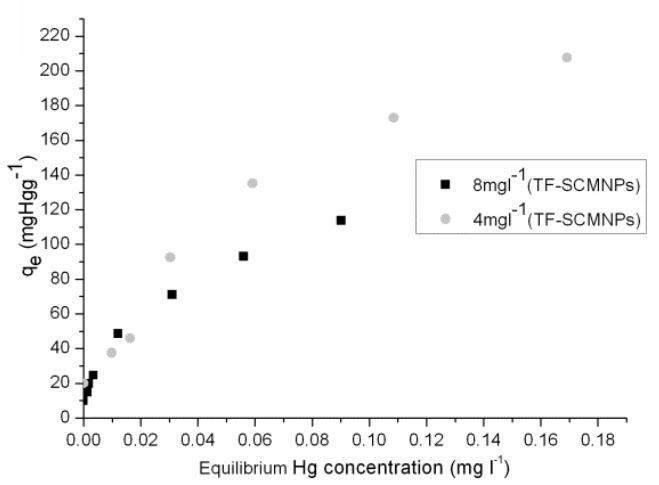

Fig. 3- Adsorption kinetic and isotherm experiments. (a) Removal efficiency using $8 \mathrm{mg} \mathrm{l}^{-1}$ of TF-SCMNPs with $80 \mu \mathrm{g} 1^{-1} \mathrm{Hg}(\mathrm{II})$ solution at $\mathrm{pH}$ 6.0. (b) Adsorption curve for 4 and $8 \mathrm{mg}^{-1} \mathrm{TF}$ SCMNPs at initial pH 6.0. 
$\mathrm{a}$

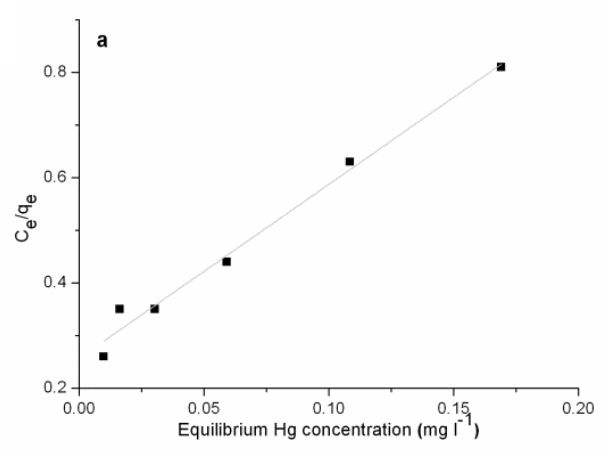

c

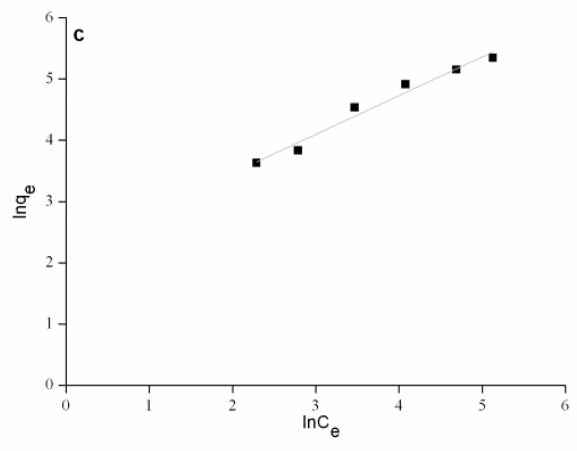

b

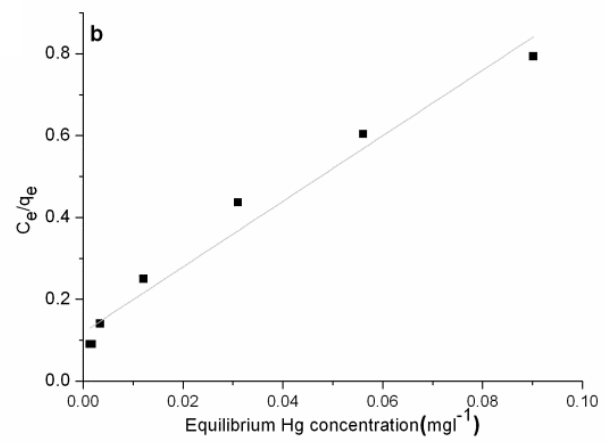

d

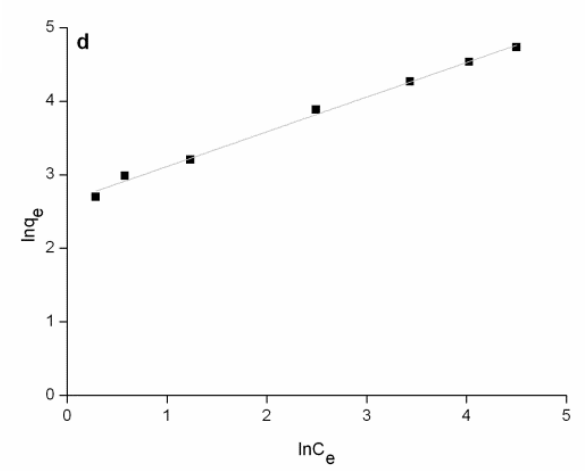

Fig. 4- Comparison of Langmuir and Freundlich isotherms for $\mathrm{Hg}(\mathrm{II})$ at $\mathrm{pH} 6.0$ using TFSCMNPs at concentrations of 4 and $8 \mathrm{mg} \mathrm{l}^{-1}$. Langmuir isotherm for TF-SCMNPs at (a) 4 $\mathrm{mg} \mathrm{l}^{-1}$ and (b) $8 \mathrm{mg} \mathrm{l}^{-1}$. Freundlich isotherm for TF-SCMNPs at (c) $4 \mathrm{mg} \mathrm{l}^{-1}$ and (d) $8 \mathrm{mg}$ $1^{-1}$. 
$\mathrm{a}$

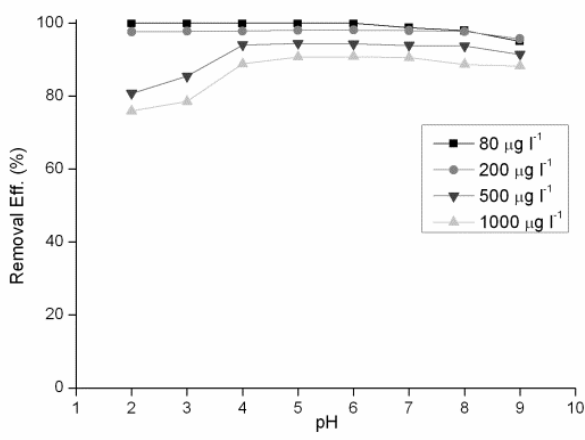

b

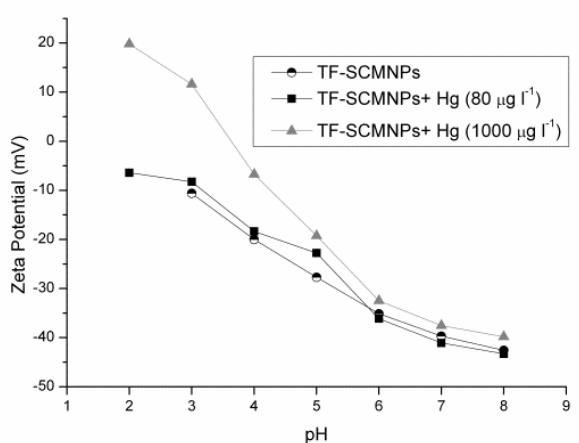

Fig. 5- Effect of $\mathrm{pH}$ on adsorption behaviour and zeta potential of TF-SCMNPs. (a) Effect of $\mathrm{pH}$ on $\mathrm{Hg}(\mathrm{II})$ removal efficiency at different initial $\mathrm{Hg}$ (II) concentrations with the TF-SCMNPs adsorbent at $8 \mathrm{mg}^{-1}$. (b) Zeta potentials at different $\mathrm{pH}$ values. 

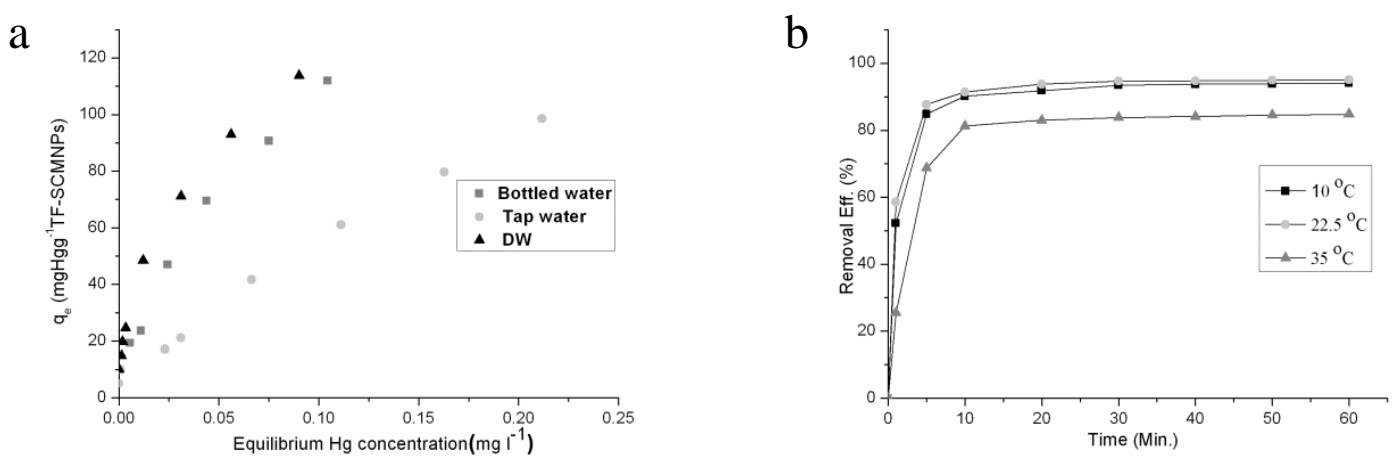

Fig. 6- Effect of competing ions and of temperature on $\mathrm{Hg}(\mathrm{II})$ adsorption by TFSCMNPs. (a) Adsorption curve for TF-SCMNPs using deionised, bottled and tap waters with TF-SCMNPs adsorbent at $8 \mathrm{mg} \mathrm{l}^{-1}$. (b) Effect of temperature on $\mathrm{Hg}$ (II) removal efficiency using TF-SCMNPs at an initial $\mathrm{Hg}(\mathrm{II})$ concentration of $160 \mu \mathrm{g} \mathrm{l}^{-1}$ solution at pH 6.0 with SCMNPs adsorbent at $8 \mathrm{mg} \mathrm{l}^{-1}$. 


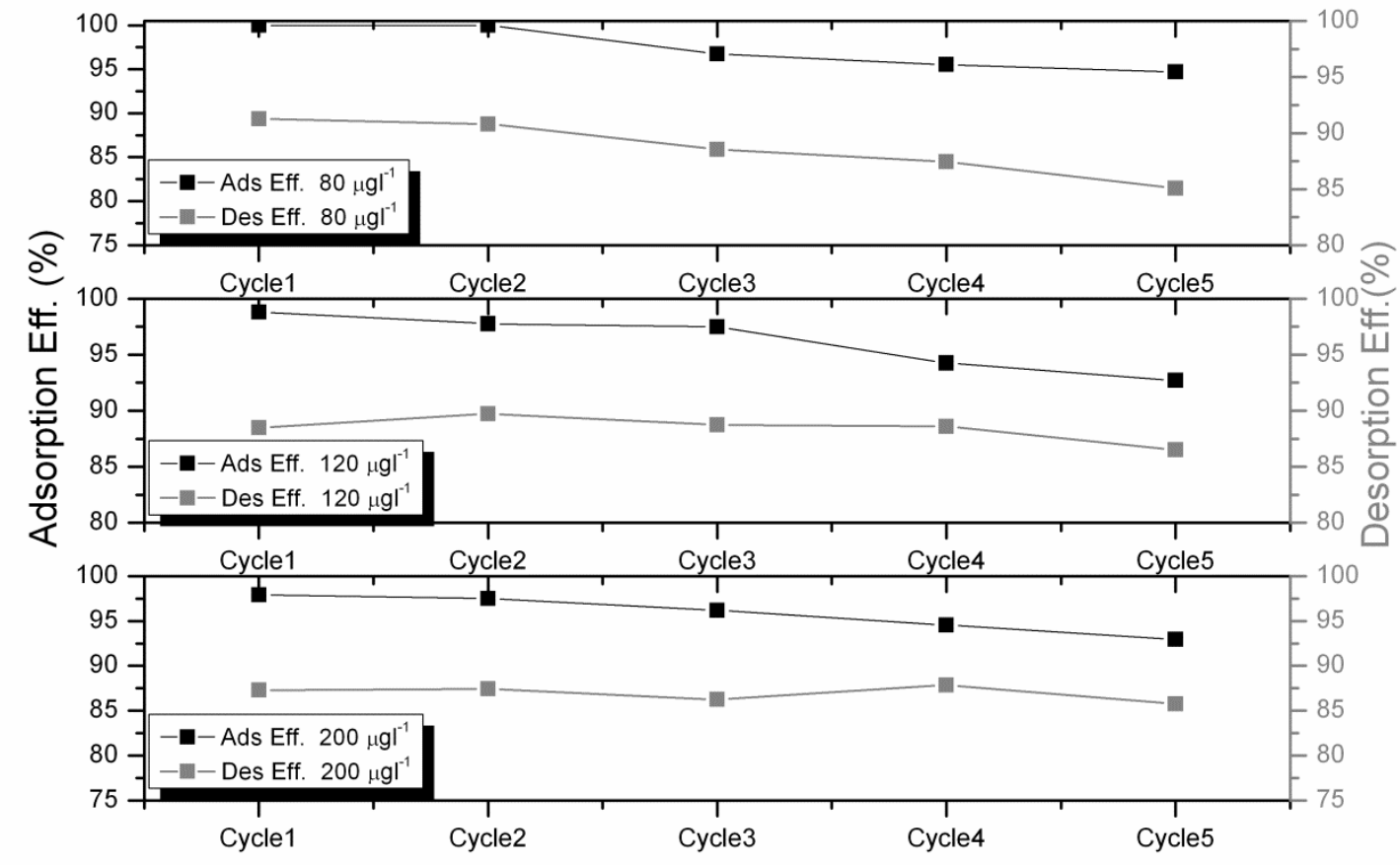

Fig. 7- Percentage $\mathrm{Hg}(\mathrm{II})$ adsorbed and desorbed during five adsorption/desorption cycles at initial concentrations of 80,120 and $200 \mu \mathrm{g}{ }^{-1}$. 
Table 1S- Equilibrium time for $\mathrm{Hg}$ (II) removal using common adsorbents.

\begin{tabular}{ccc}
\hline Sorbents & Equilibrium Time (h) & References \\
\hline Activated carbon & $2-8$ & Namasivayam and Periasamy (1993); \\
& & Namasivayam and Kadirvelu (1999); \\
& Mohan et al., (2000); Rao et al., (2009) \\
\hline Clay & $6-14$ & Viraraghavan and Kapoor (1994); Say et \\
& & al., (2008) Senevirathna et al.(2011) \\
\hline Fly ash & $48-72$ & Rio and Delebarre (2003) \\
\hline TF-SCMNPs & 0.25 & This study \\
\hline
\end{tabular}


Table 2S- Comparison of the sorption capacities of adsorbents used for $\mathrm{Hg}$ (II) removal (mg $\left.\mathrm{g}^{-1}\right)$

\begin{tabular}{|c|c|c|c|c|c|c|}
\hline 尝 & sorbent & $\begin{array}{c}\text { Max } \\
\text { capacity } \\
\left(\mathrm{mg} \mathrm{g}^{-1}\right)\end{array}$ & $\begin{array}{c}\text { Max Hg } \\
\text { conc } \\
\left(\mu \mathrm{g} \mathrm{I}^{-1}\right)\end{array}$ & $\begin{array}{l}\text { Adsorbent } \\
\text { conc } \\
\left(\mathrm{g} \mathrm{I}^{-1}\right)\end{array}$ & $\begin{array}{c}\text { Final Hg } \\
\text { conc } \\
\left(\mu \mathrm{g} \mathrm{I}^{-1}\right)^{*}\end{array}$ & Reference \\
\hline \multirow{6}{*}{ 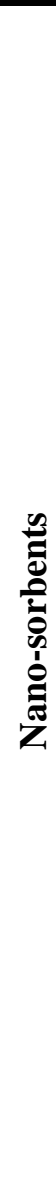 } & $\begin{array}{l}\text { Thiol-modified } \\
\text { magnetite beads- } \\
\text { porous materials }\end{array}$ & 14.0 & 60000 & 1 & 46000 & $\begin{array}{c}\text { Dong et al. } \\
\text { (2008) }\end{array}$ \\
\hline & $\begin{array}{c}\text { Magnetic NPs } \\
\text { modified with 2- } \\
\text { mercaptobenzothiazole }\end{array}$ & 0.59 & 1000 & 1 & 410 & $\begin{array}{l}\text { Parham et al. } \\
\qquad(2012)\end{array}$ \\
\hline & $\begin{array}{c}\text { Humic acid coating } \\
\text { Magnetic NPs }\end{array}$ & 97.7 & 5000 & 1 & 240 & Liu et al. (2008) \\
\hline & $\begin{array}{l}\text { Thiol-modified } \\
\text { magnetite NPs-non }\end{array}$ & 19.79 & 560 & 0.01 & 21900 & $\begin{array}{l}\text { Song et al. } \\
\text { (2011) }\end{array}$ \\
\hline & porous materials & & & & & \\
\hline & $\begin{array}{c}\text { Silica-graft } \\
\text { dimethylaminoethyl } \\
\text { methacrylate }\end{array}$ & 8.10 & 30000 & 1 & 361.1 & $\begin{array}{c}\text { Zhao et al. } \\
\text { (2011) }\end{array}$ \\
\hline \multirow{4}{*}{ 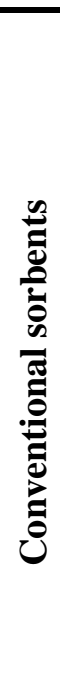 } & Zeolite & 57.5 & 470 & 2 & 200 & $\begin{array}{c}\text { Chojnacki et al. } \\
\text { (2004) }\end{array}$ \\
\hline & Clay & 0.04 & 1000 & 12.50 & 500 & $\begin{array}{l}\text { Viraraghavan } \\
\text { and } \\
\text { Kapoor (1994) }\end{array}$ \\
\hline & Clay & 0.23 & 1500 & 28 & 856 & $\begin{array}{c}\text { U Senevirathna } \\
\text { (2011) }\end{array}$ \\
\hline & Peat moss & 16.2 & 5000 & 5 & 844 & $\begin{array}{c}\text { Bailey et al. } \\
\text { (1999) }\end{array}$ \\
\hline
\end{tabular}




\begin{tabular}{cccccc}
\hline Fly ash & 2.5 & 10000 & 20 & 1000 & $\begin{array}{c}\text { Sen and De } \\
(1987)\end{array}$ \\
Activated carbon & 109.89 & 200000 & 0.48 & 128000 & $\begin{array}{c}\text { Namasivayam } \\
\text { and }\end{array}$ \\
& & & & & Kadirvelu \\
& & & & & \\
Activated carbon & 22.28 & 140000 & 0.50 & 129000 & Rao et al. \\
& & & & & (2009) \\
\hline TF-SCMNPs & 207.7 & 1000 & 0.004 & 169 & This study
\end{tabular}

\footnotetext{
* Some of the final $\mathrm{Hg}$ concentrations were not present in some references, but calculated according to other experimental parameters.
} 
Table 3S- Typical chemical analysis of drinking water.

\begin{tabular}{llll}
\hline Cations & Concentration $\left(\mathrm{mg} \mathrm{l}^{-1}\right)$ & Anions & Concentration $\left(\mathrm{mg} \mathrm{l}^{-1}\right)$ \\
\hline $\mathrm{Mg}^{2+}$ & 26 & $\mathrm{SO}_{4}{ }^{-2}$ & 12.6 \\
$\mathrm{Ca}^{2+}$ & 80 & $\mathrm{Cl}^{-}$ & 6.8 \\
$\mathrm{Na}^{+}$ & 6.5 & $\mathrm{NO}_{3}^{-}$ & 3.7 \\
$\mathrm{~K}^{+}$ & 1 & $\mathrm{~F}^{-}$ & 0.16 \\
& & $\mathrm{HCO}_{3}^{-}$ & 360 \\
\hline
\end{tabular}


a- Synthesis of magnetic NPs

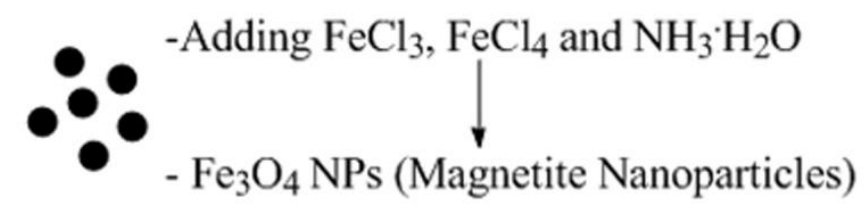

b- Synthesis of SCMNPs

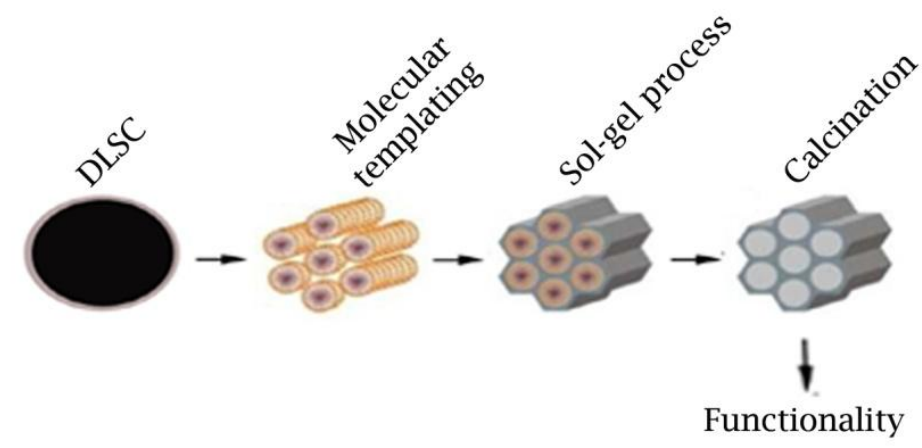

c- Synthesis of SH-SCMNPs

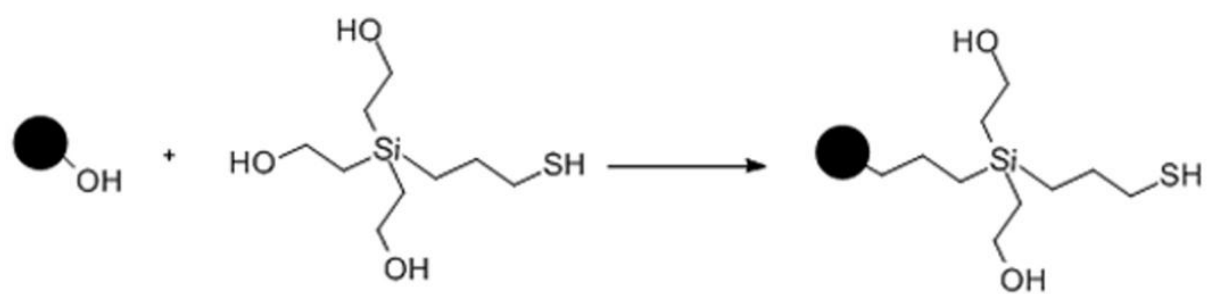

Fig. 1S- 3 stages in the production of TF-SCMNPs. 

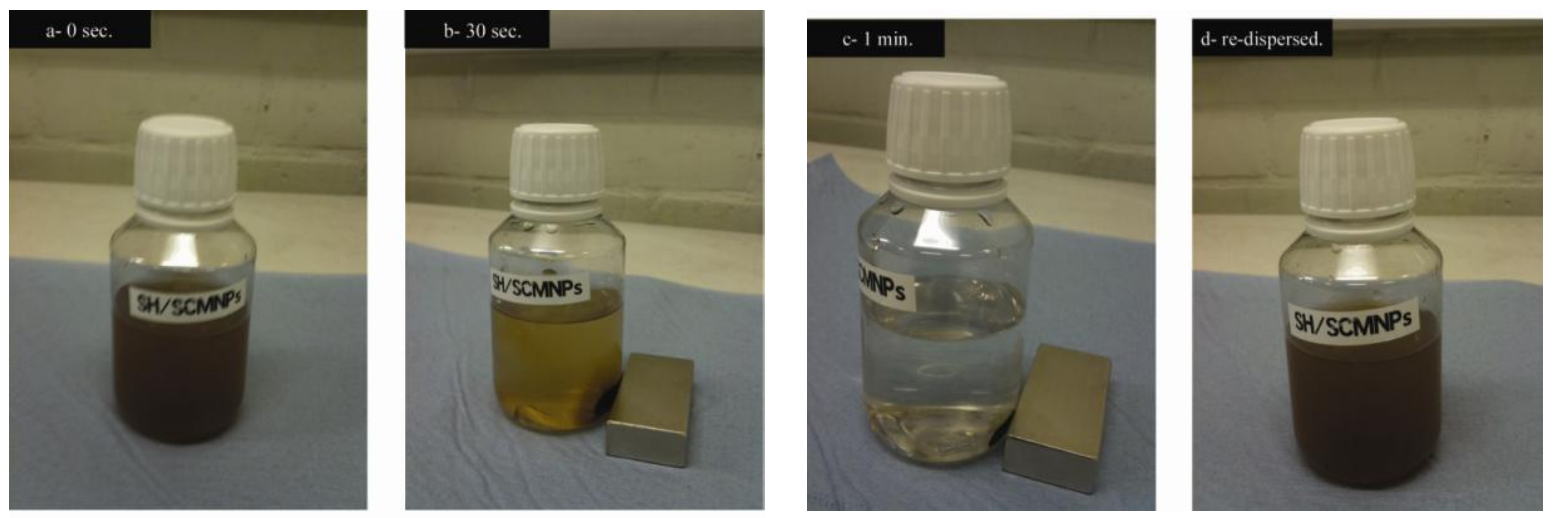

Fig. 2S- Magnetic separation at (a) $0 \mathrm{sec}$, (b) $30 \mathrm{sec}$., (c) 1 min. and (d) re-dispersed. 


\section{References for the supplementary information}

Bailey, S.E., Olin, T.J., Bricka, R.M. and Adrian, D.D. 1999.A review of potentially lowcost sorbents for heavy metals. Water Research 33(11), 2469-2479.

Chojnacki, A., Chojnacka, K., Hoffmann, J. and Górecki, H. 2004.The application of natural zeolites for mercury removal: from laboratory tests to industrial scale. Minerals Engineering 17(7-8), 933-937.

Dong, J., Xu, Z. and Wang, F. 2008.Engineering and characterization of mesoporous silicacoated magnetic particles for mercury removal from industrial effluents. Applied Surface Science 254(11), 3522-3530.

Liu, J., Zhao, Z. and Jiang, G. 2008.Coating Fe3O4 magnetic nanoparticles with humic acid for high efficient removal of heavy metals in water. Environ. Sci. Technol 42(18), 6949-6954.

Mohan, D., Gupta, V., Srivastava, S. and Chander, S. 2000.Kinetics of mercury adsorption from wastewater using activated carbon derived from fertilizer waste. Colloids and Surfaces A: Physicochemical and Engineering Aspects 177(2-3), 169-181.

Namasivayam, C. and Kadirvelu, K. 1999.Uptake of mercury (II) from wastewater by activated carbon from an unwanted agricultural solid by-product: coirpith. Carbon 37(1), 79-84.

Namasivayam, C. and Periasamy, K. 1993.Bicarbonate-treated peanut hull carbon for mercury (II) removal from aqueous solution. Water Research 27(11), 1663-1668.

Parham, H., Zargar, B. and Shiralipour, R. 2012.Fast and efficient removal of mercury from water samples using magnetic iron oxide nanoparticles modified with 2mercaptobenzothiazole. Journal of Hazardous Materials 205-206(0), 94-100. 
Rao, M.M., Reddy, D., Venkateswarlu, P. and Seshaiah, K. 2009.Removal of mercury from aqueous solutions using activated carbon prepared from agricultural by-product/waste. Journal of environmental management 90(1), 634-643.

Rio, S. and Delebarre, A. 2003.Removal of mercury in aqueous solution by fluidized bed plant fly ash. Fuel 82(2), 153-159.

Say, R., Birlik, E., Erdemgil, Z., Denizli, A. and Ersöz, A. 2008.Removal of mercury species with dithiocarbamate-anchored polymer/organosmectite composites. Journal of Hazardous Materials 150(3), 560-564.

Sen, A.K. and De, A.K. 1987.Adsorption of mercury(II) by coal fly ash. Water research 21(8), 885-888.

Song, B.Y., Eom, Y. and Lee, T.G. 2011.Removal and recovery of mercury from aqueous solution using magnetic silica nanocomposites. Applied Surface Science 257(10), 4754-4759.

U Senevirathna, W., Zhang, H. and Gu, B. 2011.Effect of carboxylic and thiol ligands (oxalate, cysteine) on the kinetics of desorption of $\mathrm{Hg}$ (II) from kaolinite. Water, Air, \& Soil Pollution, 1-12.

Viraraghavan, T. and Kapoor, A. 1994.Adsorption of mercury from wastewater by bentonite. Applied Clay Science 9(1), 31-49.

Zhao, L., Sun, J., Zhao, Y., Xu, L. and Zhai, M. 2011.Removal of hazardous metal ions from wastewater by radiation synthesized silica-graft-dimethylaminoethyl methacrylate adsorbent. Chemical Engineering Journal 170(1), 162-169. 